\title{
A Proposed Contingency Plan for Education Continuity in COVID-19 Crisis
}

\author{
Kifaya Sabbah \\ Faculty of Educational Sciences \\ and Teachers' Training \\ An-Najah National University \\ kifaya.sabbah@stu.najah.edu
}

\author{
SafiaTarteer \\ Faculty of Educational Sciences \\ and Teachers' Training \\ An-Najah National University \\ safyyah.atyyah1983@gmail.com
}

\author{
Samira Mahmoud \\ Faculty of Educational Sciences \\ and Teachers' Training \\ An-Najah National University \\ samira.mahmoud@stu.najah.edu
}

Received 6/6/2021

Accepted 25/7/2021

\begin{abstract}
:
This study aims to create a contingency plan for the emergency period during COVID-19 pandemic. The researchers read the exiting plans to put a suitable one for Palestine. They have revised the literature to benefit from it. The result was to put a suitable contingency plan for COVID-19 period. It included preparedness, providing first aid, notifying response partners, and providing instruction before first responders arrive. Preparedness is defined around five missions: Prevention, Protection, Mitigation, Response, and Recovery. SWOT analysis and interview as a case study are adopted to include the plan's all dimensions of how to behave during the pandemic. The researchers present some recommendations for both teachers and students, that teachers should train themselves on how to use ICT. At the same time, students should show positive attitudes towards using ICT in learning.
\end{abstract}

Keywords: Contingency plan, COVID-19.

\section{1- Introduction:}

Education has been globally accepted as a fundamental right for all, and it should be available without restriction. It cannot be separated from a person's life. In fact, it is important to live with happiness and prosperity, and it empowers minds that would be able to conceive good thoughts, ideas, and in making life decisions. It plays an important role in the development of a country. If a country does not have propped education, it may be left behind by other countries which support education. There are many factors that affect the education system; culture, technology, and economic matters give much impact to the education system of a country ${ }^{1}$ (Pherali).

Education is a humanitarian need. It is a human right in itself, but sometimes this right is taken away by conflict or disaster ${ }^{2}$ (De Oliveire), this opens the way to education in emergency in light of the urgent circumstances that the countries of the world are going through due to the spread of Covid-19 which led to the closure of schools in most countries ${ }^{3}(\mathrm{Wu})$, about 300 million students around the world are sitting in their homes today, after the governments of their countries issued decisions to close schools, according to the latest report issued by $\mathrm{UNICEF}^{4}$ (Alamo). Traditional school methods are no longer the medium available to millions of students around the world whose schools have been closed, and millions more may have their schools closed at any time ${ }^{5}$ (Huang).

This precedent, which had not occurred before in the history of education, forced millions of students to commit to their homes, and prompted those in charge of education to come up with unconventional ideas to mitigate the negative effects of disrupted school life ${ }^{6}$ (World Health Organization). To solve the problem of school's closure, many of them rushed towards remote education via the Internet to communicate and contact, receive and answer questions, or provide students with educational helping websites, or mention the sites to undergo and correct electronic educational tests. In addition, capabilities of visual communications were activated to hold oral and mathematical tests. Successful policy implementation requires mobilizing the knowledge and experience of teachers and school leaders, the people who can make the practical connections between the classroom and the changes taking place in the outside world. That is the fundamental challenge of policy implementation today $^{7}$ (Porcheddu).

Nowhere today is higher education undergoing more substantial change in Europe ${ }^{8}$ (Morality), as countries pursue policies designed to integrate their economy, political system, and social structure. It is becoming increasingly clear that higher education research and innovation are critical components to fully realize the potential gains stemming from the changes ahead. This idea has been promoted in several high-level 
European wide processes and has given rise to a series of ambitious goals and objectives designed to ensure long term pre-eminences as both a knowledge producer and transmitter ${ }^{9}$ (Cantillo).

Italy is one of the four countries that reform the educational system in Europe. It is like some European countries in terms of education, the reform process is occurring also in the education sector. It began reform with kindergarten, whose system is like any ordinary country and ends with higher education, a comprehensive reform of institutional governance and internal organization of Italian State University, which proclaims autonomy and accountability as its basic principles. The structure of the Italian Universities has radically changed since 2000/2001. The reform of Universities has two purposes: One of them is obtaining a degree within three years by most students who are able to enter the world of work, and guaranteeing the usefulness of the qualification to seek professionalism and employment ${ }^{10}$ (Nacoti).

In this paper, we discuss education in regular situation, and in crises, throughout Covid-19 crisis, and educational system in Italy. Then we introduced some recommendations to develop the educational system there in lights of our findings in this report, hopefully, to benefit from these findings in developing the educational system in Palestine during crises. In fact, education is the key to success in the future and to have many opportunities in life. It is maintained during emergency, conflict, and postconflict situations; when communities have lost everything, education remains a top priority ${ }^{11}$ (Naziev).

\section{Literature Review}

The researchers revised the previous literature about COVID-19 condition spread, and the previous related studies. They divided it into the following sections:

\section{2 -Education in Emergency}

Education is important for sustainable development and peace. Every goal in the 2030 agenda requires education to empower people with the knowledge, skill, and values to live in dignity, build their lives, and contribute to their societies. Emergency education is used at inter-agency level to refer to education in situations where children lack access to their national education system, due to manmade crisis or natural disasters ${ }^{2}$, for UNESCO, this crisis situation created by conflict or disasters which have destabilized, disorganized, or destroyed the education system, but UNICEF revealed that emergency include natural disasters such as floods and earthquakes, human-made crisis such as civil strife and war, as well as silent emergencies such as diseases, the cholera outbreak of 2017 in Yemen ( ${ }^{12}$ Montjourides; ${ }^{13}$ Ellis), and the latest Coved-19 pandemic, extreme poverty, and children living in the stress $^{6}$.

Education is essential in emergency, because of the psychological needs of children, adolescents, and persons with disability affected by trauma and displacement, the need to protect them from harm, and the need to maintain and develop study skills ${ }^{13}$. In addition, education is increasingly viewed as the "fourth pillar" or humanitarian response of shelter and health service ${ }^{8}$. It provides opportunities for students to learn the skills and values needed for a more peaceful future and better governance at local and national levels. It is psychologically beneficial to refugees, and other crises affecting children. These psychological benefits together with learned knowledge, skills, and values can contribute to peacebuilding, social, and economic development because education can serve as a tool of protection from harm. UNESCO helps strengthen the education system in time of crisis to ensure peace-building and life-saving messages reach children and their families, and protect children and youth from attack, abuse, and exploitation ${ }^{14}$ (Burde).

Meanwhile, crises affect education and children in one way or another, whether in the form of political, economic, health, or environmental crises. According to UNICEF, $36 \%$ of the world's 59.3 million out of schools children live in countries affected by war and violence. Schools and universities that had been taken over for many purposes were internationally targeted for attacks over the last few years. Children need education more during emergencies because it provides children with the stability, structure, and routine they need in order to cope with loss, fear, violence, and hardship during and after crisis ${ }^{4}$.

Education for disasters risk reduction used novel methods, including electronic media and simulation exercises to make them more user-friendly and appealing to children. Corona virus crisis have changed how students are educated around the world. Those changes gave us a glimpse at how education could change for the better and the worse in the long term with the corona virus spreading rapidly across Asia, Europe, the Middle East, and the United States, all countries are using online educational platforms, teachers teach students remotely ${ }^{15}$ (Khan). It is also important that educational exercise, technology, and distance learning were involved by UNICEF in the areas that suffer from conflict and were found to make them (friendly users). Educational authorities develop more electronic study material to ensure their access to education ${ }^{16}$ (Loader). 
3- Education, Health, and Society in Coved-19 period

\section{3-1 Education Sector}

With the spread of Covid-19, the whole world became under a state of emergency, countries are implementing emergency plans to slow down and limit the spread of the virus and prepare for a possible longer-term disruption of school and university attendance. In a matter of weeks, the corona virus changed the way of learning around the world ${ }^{6}$. In Italy, Universities made impressive efforts to digital courses, exams and research activities that do not require lab work, amid a country-wide quarantine announced by the government ${ }^{17}$ (Sun). To fight the virus, the government took sweeping measures, including closing down university campuses and restricting the movement of all people with the exception of employees who need to travel to work $^{18}$ (Paules).

Students returned from studying abroad. Universities in Italy moved their courses online while some were able to give exams and hold dissertation defense through web conferencing. Academics decided to cancel conferences and public events and even close their libraries to the public ${ }^{15}$. They were also looking at the crisis as an opportunity for universities to adopt digital technology for teaching more broadly, not just in times of crisis ${ }^{10}$. They hoped their experiment could be used in other countries. CT staff worked nearly 20 hours a day for two weeks, to put the systems in place. Academics carried on working online as much as possible, conducting interviews on Skype. There were free online newspapers, faster internet and access to elearning platforms. Additionally, mobile phone companies gave extra digital data. This led students at schools into temporary "home-schooling" situations. They learned material through live television broadcast, via WhatsApp, and e-mails ${ }^{6}$, ${ }^{19}$ (Setiawan).

\section{3-2 Health Sector}

Coved-19 is probably one of the most challenging threats to national and international public health. Initially, the healthcare workers were placed in a stressful condition ${ }^{20}$ (Kumari, 2020; ${ }^{21}$ Parry, 2020). In a situation like this, it is normal to feel sad, worried, confused, sacred, or angry. Great efforts were exerted by the Italian health authority. Corona virus started there via Chinese tourists from Wuhan who travelled in the northern region of Italy, they visited the city of Milan then the virus spread all around. The number of cases in Italy increased beyond expectation, putting the Italian health under considerable strain $^{22}$ (Hui). Cases were found in several bordering regions and autonomous provinces of northern Italy ${ }^{6}$

The Prime Minister was afraid from the charge of implementing healthcare but he didn't prepare to face a national emergency deployed by the region and provinces such as quarantine ${ }^{22}$. The situation in Italy is dismal; the hospital is highly contaminated, 300 beds out of 900 are occupied by covid-19 patients. Fully $70 \%$ of ICU beds in hospitals are served critically with covid-19 patients with a reasonable chance to survive ${ }^{6}$. Most hospitals are overcrowded, nearing collapse while medications, mechanical ventilators, oxygen, and personal protective equipment are not available. Patients lay on the floor mattresses ${ }^{7}$; cemeteries are overwhelmed. In hospitals, health care workers and ancillary are alone, trying to keep the system operational.

After China, Italy has now the second largest number of covid-19 patients. The virus spread quickly in Italy because $23 \%$ of Italian population are aged 65 years or older 6 . During the outbreak, regional authorities can actively slow the spread of infection, as countries do with their borders ${ }^{22}$. During that, the authorities need to trace contacts and track people's movements; healthcare providers must identify high risk cases creating staff shortages ${ }^{23}$ (Leonardi).

\section{3-3 Community}

Beyond hospitals, communities were neglected; people had been in quarantine since March $10^{\text {th }}$. The outbreak was out of control. The situation changed from patient-centered care into communitycentered care. Home care and mobile clinic avoided unnecessary movement and released pressure from hospitals ${ }^{10}$. The Prime Minister called the crisis "national emergency", he stopped social interaction 
and air traffic from China, he organized repatriation flights and quarantines for Italian travelers in China, he limited the movement for those living in the country's north, and he asked to close restaurants, cinema and theatres, schools, and soccer, and only grocery stores and pharmacies were allowed to stay open to control the spread of the virus. In fact, the virus did not follow geographical boundaries, ethnicities, age, ability, or gender so it was important not to stigmatize peers or tease anyone about being sick. In fact, understanding basic information about coronavirus disease (Covid-19) was very important to stop the spread of the virus ${ }^{24}$ (Mazzucato).

\section{4 - The Educational System in Italy}

Education in Italy has a distinguished position and is given great interest from educational and social institutions; families play a key role in the educational process, they keep in touch with the school to follow on their children. In addition, what is remarkable about Italy's educational policy is the attention that the state attaches to the position of the teacher in terms of preparation and qualification, in addition to the attention to his economic situation. To develop schools, the Italian Ministry of Education launched, in 2007, a National Plan for Digital Schools to mainstream Information Communication Technology (ICT) in Italian classrooms, hopefully leading to new teaching practices, and new models of school organization, to support quality teaching ${ }^{23}$.

The plan was set in order to achieve two objectives: to speed up the uptake of ICT in Italian schools, and to create an Innovation Laboratory Network and invent new pedagogic and organizational practices to improve Italian education $^{25}$ (Burberi). Education in Italy is a good system that prepares the student and quickly qualifies him for the job market, to prepare them for life, by providing the appropriate conditions for developing their personality in all moral, social, mental, functional, and creative directions ${ }^{26}$ (Contini, 2018). The costs are affordable for everyone. Study in Italy is around 9 months of the year, beginning in midSeptember, and ending in June. There are public and private schools but the quality of the public schools is also high compared to the private schools. The System is divided into:
1. Up to Age 3: Day nursery.

2. Ages 3 to 6: Nursery school.

3. Ages 6 to 10: Elementary school.

4. Ages 11 to 14: Middle school.

5. Ages 15 to 19: High /Secondary school, academic and technical stream ${ }^{27}$ (Comi).

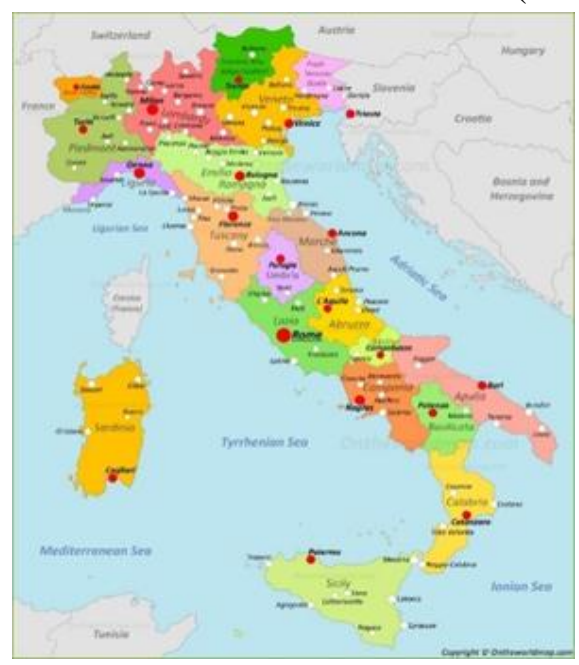

\section{4-1 Elementary and Lower Secondary Education}

The elementary school has a duration of 5 years and it falls under the list of compulsory education for the student. All students have to take an exam at the end of primary education to enter the new stage and spend 3 years at the preparatory stage and the student is then qualified for the secondary stage, which is the most important stage in Italy because it is the stage that qualifies the student for the final stage which is the university, which precedes the labor market. During the ten years of compulsory education, as mentioned above, all books are free for the student, and they only purchase their own school tools. Primary school programs include the following subjects: The Italian language, a foreign language, mathematics, science, history and geography, civil studies, religion, painting, music, and physical education.

The secondary stage lasts 5 years, and is divided into two branches; the first division: which is the first two years, and the second division: the last three years, and at the end of that stage the student must pass an examination determined by the state to go to the last stage which is the university stage, and in this stage, the student can choose the type of secondary education he wants ${ }^{26}$. As for the education 
programs in the middle secondary stage, they include the following subjects: Religion (elective subject), Mathematics, Physics, Chemistry, Natural Sciences, Italian Language, History, Geography, Foreign Language, Civil Sciences, Technical Education, Music, in addition to Physical Education ${ }^{25}$.

\section{ITALIAN SCHOOL STRUCTURE

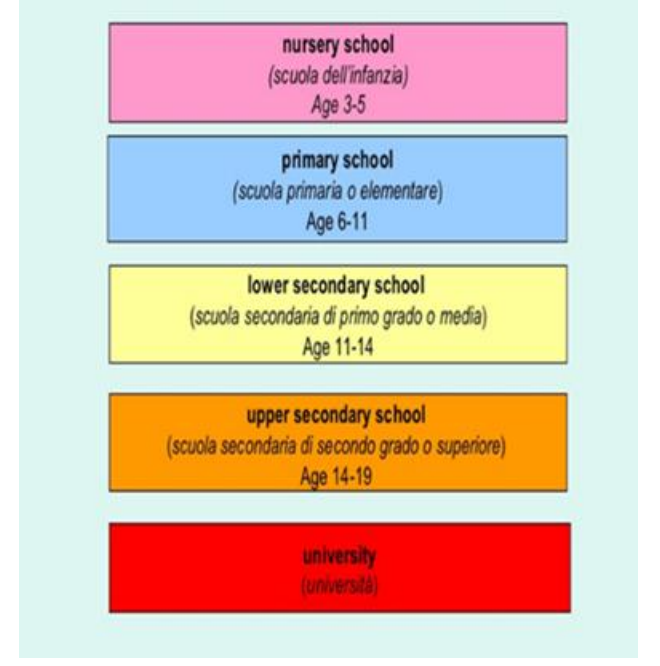

In 2013, the program for International Student Assessment, coordinated by the OECD, ranks the Italian secondary education as the $21^{\text {st }}$ in the world, above the United States and in the OECD average, and observes a wide gap between results in Northern Italian schools, which performed significantly better than the national average (among the best in the world in some subjects), and Southern Italian schools had much poorer results. Moreover, students in stateowned schools perform better than students in private schools ${ }^{25}$.

\section{4-2 Higher Education in Italy}

Over a million students attend institutes of higher education in Italy. The country has around 90 institutes of higher education, including 47 state universities, several private universities and over 20 institutes of physical education. There are also two universities of Italian language and culture. There is a university in every major city in Italy, some with a number of branches situated in different towns throughout a region. The University of Bologna $\left(11^{\text {th }}\right.$ century) is the world's oldest and highly regarded, while Rome has three universities, the oldest being La Sapienza ${ }^{28}$ (Turk, 2019). Other higher education facilities include the University Naval Institute in Naples and the College of Education in Pisa. Higher education is controlled by the Ministry of Universities. Universities are organized into faculties for different teaching subjects and departments, which are in charge of research ${ }^{29}$ (Rogers, 2019). The Italian higher education system includes: 1. Public and Private Universities, 2. The Higher Education universities and Institutes for Fine Arts, Music, and Dance sector, and 3. On-line universities ${ }^{25}$.

The Italian University system is organized in four cycles defining the academic qualifications ${ }^{2725}$. First, Undergraduate Degree-Laureus: The Laurea, which is equivalent to a Bachelor of Science after a three-year program of study. Second, a Graduate degree (PHD). It is the highest level of university. The PHD academic qualification obtained after a long study lasting at least three years. Third, Specializing Masters and Continuing Education programs: aimed at increasing students' professional education. ${ }^{30}$ (Macaro, 2018). Fourth, Higher Technical Institute: It's a program that provides theoretical background and prepares students for the real-world requirement. The courses cover six main technological areas: Energy efficacy, Sustainable mobility, new technologies for life, Innovation Technologies for Cultural Activities and Tourism, Information and Communication Technologies, and New Technologies Made in Italy ${ }^{27}$. 


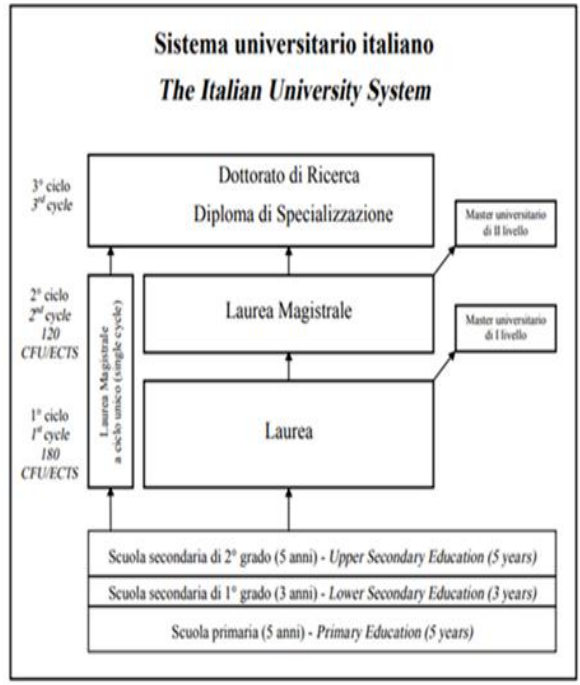

The Study of Language is normal in Italy; language courses are taught by foreign languages. In addition, Universities have a local assessment committee to draw up a yearly report to be sent to the National Assessment Committee, the committee sometimes relies on students' assessment and feedback questionnaire which provides a large amount of information about the quality of teaching. They don't replace written and oral examinations.

University teaching requires a doctorate degree in the field of specialization. The faculty committee of deans, professors, and researchers, coordinates and carries out the academic responsibilities of the university related to curriculum, scholarships, and student advising ${ }^{31}$ (Blazar). The committee makes decisions about teaching and research. Students may be part of this committee. Inspectors visit schools may be part of this committee. They visit schools to ensure that educational objectives are being met. University rectors are responsible for posting recruitment needs, procedures, and competitive exams $^{10}$.

University faculty includes full professors and associate professors. Additionally, research professors contribute to the development of research and integrate and apply it to their teaching in universities in Italy that focus on two tasks, teaching and research. This provides considerable academic autonomy and freedom for students to pursue courses of study. The federal government finances public education by providing salaries, purchasing textbooks and other materials, even online materials, through coved-19 crises. Italian Universities supported services such as online library services, and print material available online, phone, or internet-based counseling support or study groups enabled through digital media. It also covered face to face lessons into online lessons and how to train faculty members to do so ${ }^{32}$ (Ansah).

\section{The Problem of This Study}

The whole world closed down because of the spread of COVID-19 pandemic. Most educators and school teachers were not trained to teach remotely. They started to put suitable plans to continue their education peacefully. In Italy, Universities were not ready to face the closure. In response to this gap in knowledge, this study came. It aims to create a contingency plan based on analyzing some plans from all over the world to help people in Palestine and the rest of the world to continue the learning process as usual. This study came also to compare between the situation in Italy in normal situation, and in crises situation.

\section{The Purpose of This Study}

This study may help stakeholders to continue the learning process remotely. It may also draw the attention of the Ministry of Education towards the importance of training teachers and the University educators and professors to train themselves and their students on how to use ICT in teaching and learning and how to interact with it to create a positive attitude towards it to achieve success. Besides, it will reveal the situation during the spread of COVID-19 pandemic. This study may attract stakeholder's attention to reform ICT infrastructure to be suitable to use e-learning in crises. In fact, this study is considered one of the first studies conducted about continuing education remotely.

\section{Methodology:}

\section{Tools and Data Collection}

The researchers revised the previous literature to have a look at what others wrote about COVID-19 closure and what plan they have put to guarantee education continuing during the pandemic. It included preparedness, providing first aid, notifying response partners, and providing instruction before first responders arrive. Preparedness is defined around five missions: Prevention, Protection, Mitigation, Response, and Recovery. ${ }^{33}$ Mudavanhu pointed out that literature is very important to judge the quality of any research; it is useful in discussing the results of the study and strengthens the study itself. They also conducted an interview (case study) 
with faculty member in Italy to see how his university continued teaching remotely during the pandemic. Teegavarapu $(2008)^{34}$ pointed out that using a case study achieves a systematic research. It provides multiple mode of collecting data. The researchers analyzed documents for many countries such as the UK, and the USA to see what they have put to deal with educational process during the pandemic. White et al. ${ }^{35}$ revealed that content analysis achieves highly flexible research and employs a wide range of analytical techniques to generate findings and put them into context. One of the most necessary procedures to develop a contingency plan is SWOT analysis that aims at measuring the strengths, weaknesses, opportunities, and threats. Gurel ${ }^{36}$ revealed that using SWOT analysis in research enables engaging and organizing the strategic planning. It helps planning to be more productive. The researcher aimed to analyze the Education System in Italy, based on the literature and the information collected about the Italian Educational System from a faculty member in one of the Italian universities.

\section{Sample and the population of the study}

The sample was some documents that have been put down to guarantee continuity of the learning process during COVID-19 pandemic. It also included professors from an Italian University to tell us about the situation during the spread of COVID-19. The population was Italian people, the researcher describes the situation in Italy in the normal and in the crises case.

\section{Contingency Plan for Educational System Continuity during the Crises}

The development of the education sector is one of the most important goals of the SDGs. Consequently, resilience and cohesion of any educational system is very important in exceptional crises. Resilience of vital systems, including education, depends on flexibility of procedures and decisions, as well as efficient partnership and collaboration among educational stakeholders including MOE, directorates, managing and teaching staff, students, and their parents. All have a central role for continuing the educational process and providing appropriate knowledge and skills under exceptional crises.

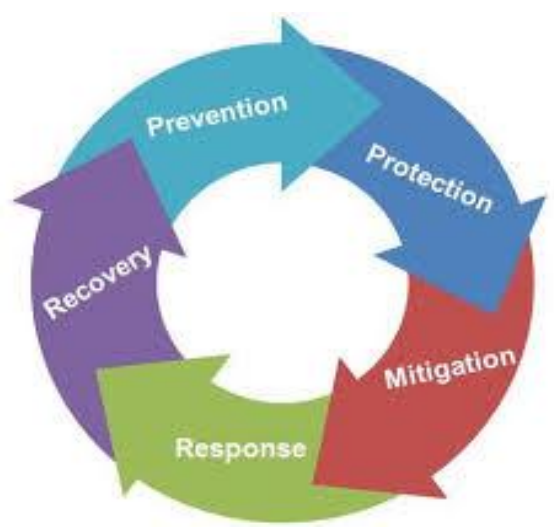

Governments should be prepared for such crises by developing educational contingency plans that involve alternative processes and recovery strategies, so that all the necessary resources are available to bring the system back to its normal operation using the minimum resources in the least possible time. The main objective is to respond immediately to keep students and staff safe by taking preventive and protective measures to stop an emergency or reduce the impact of an incident. This includes preparedness, providing first aid, notifying response partners, and providing instruction before first responders arrive. Preparedness is defined around five missions: Prevention, Protection, Mitigation, Response, and Recovery ${ }^{37}$ (Fernandes).

Effective contingency planning and development are not done in isolation, but educational institutions should work with district staff and community partners, such as local emergency management staff, first responders, and public and mental health officials. An effective plan should be supported and integrated with district, community, regional, and state plans to make more resources available and help to ensure seamless integration of all responders. This article goes through the educational contingency plan of the Italian universities and schools, which decided to go digital as a country-wide quarantine is announced by the government due to coronavirus, and classrooms were no longer open. They have made impressive efforts to digitize courses, exams and research activities that do not require lab work. 
One of the most necessary procedures to develop a contingency plan is SWOT analysis that aims at measuring the strengths, weaknesses, opportunities, and threats. Appendix B summarizes the SWOT analysis of the Education System in Italy, based on the literature and the information collected about the Italian Educational System from a faculty member in one of the Italian universities.

The proposed contingency plan targets all stakeholders including the academic leaders and managers, the teachers, the students and the community within three main strategic objectives that divide into 7 sub objectives (the detailed contingency plan is shown in Appendix C):

- Awareness Level: This concentrates on raising the awareness level of all stakeholders, including academic managers, teachers, and students, in both protection against the virus and the educational practices.

- Periodic Evaluation and Decision Making: This includes evaluation of the current situation and decision making on the procedures to be taken regarding the educational resources and tools. Additionally, it focuses on providing the necessary requirements and needs of teachers and students.

- Skills and Performance Level: This involves developing training programs for managers, teachers and students to raise their skills and performance level in both general ICT skills and educational technologies and tools.

\section{Reflection and Recommendation}

Our vision towards the educational system figures out the required change to cope with the digital revolution and the best methods to activate student motivation and innovation and to enhance the teaching and learning practices. It investigates the appropriate digital technologies and tools as well as the training programs that meet the future needs to access across-borders labor markets. Furthermore, it determines how we can pass, with our students and teachers, to develop their skills, experience and creative thinking to achieve meaningful and internationalized education. At the same time, it should not marginalize education at the national level.

In light of the proposed contingency plan for education continuity in Italy, both universities and schools in Italy vary in preparedness to face the contingency, in terms of ICT infrastructure, utilities and student achievement. The first bologna declaration for educational reform was announced in an Italian university. The Italian government and the Ministry of Education, University and Research started its digital transformation in education very early. Therefore, several e-learning platforms were developed in Italy, which provided more flexibility for universities and schools to employ them free-ofcharge. Moreover, teachers have incentives and motivation, as they are qualified and well prepared.

All these strengths enabled the educational process to move smoothly in the majority of schools and universities, where each made its decision regarding the contingency. They continued using elearning for providing the educational content and delivery. The main challenges were related to student assessment methods and practical parts that need laboratories. They overcome the first challenge by eproctoring of written exams and online platforms for oral exams and thesis discussion. Unfortunately, they could not find a good alternative for the practical part that needs workshops and laboratories.

The academic managers should provide progress reports to the MOEUR, which include achievements of schools and universities, obstacles, requirements, and suggested solutions that support decision-making. Moreover, they should follow up teachers training and asses their performance. They have to facilitate the educational process, encourage teachers and students to do their best to continue teaching and learning respectively. Besides, they are responsible for teachers' and students' positive mental attitude and collaborative skills. In addition, academic managers should suggest and participate in developing solutions to the main obstacles. They have to measure the preparedness of students, parents, and school environment. They should also benefit from lessons learnt on the national and international levels.

Teachers have a key role in crises, since they are responsible for continuing the teaching process by encouraging their students to ensure positive attitudes towards learning in crises. Moreover, they should design effective learning activities that support 
students' engagement and active participation, and increase students' abilities in analysis, reasoning, and communication. Moreover, qualified teachers should be selected as trainers in the training programs that help lower-skilled teachers. Besides, they should practice student-centered learning, integrate ICT into teaching and learning strategies. They have to exchange experience with their colleagues in other countries. In addition, they have to attend the planned teacher professional training programs in order to enhance their planning for lessons from distance, especially in crises.

On the other hand, students have to adapt to the emerging learning methods and to be active learners during the emergency period. They have to show positive attitudes towards the instructions of their teachers related to the new methods of teaching and assessing their performance and learning. In addition, students should attend awareness and training programs to cope with the new researchbased and ICT-enhanced learning strategies. They should utilize extra time in useful activities, and should be motivated to benefit from the new education system.

Our message to every teacher in universities and schools: gradually teach your students, a few electronic minutes are enough for each subject during which you present the most important concept that a student should know with an interesting template, in which the content and tasks should be divided, and how much education becomes realistic if it is related to the crisis, we live in. Help the students to become soldiers who contribute to raising awareness of the imminent danger, and do not underestimate their role. Don't forget the students' needs for their teachers are greater. Therefore, all educators must show wisdom; otherwise they will lose students and their attitudes toward complete learning. Little by little, achieve the goals and make all overcome this crisis.

\section{References}

1. Pherali, Tejendra, Mai Abu Moghli, and Elaine Chase. "Educators for change: Supporting the transformative role of teachers in contexts of mass displacement.", (2020).

2. De Oliveira Araújo, Francisco Jonathan, Ligia Samara Abrantes de Lima, Pedro Ivo Martins Cidade, Camila Bezerra Nobre, and Modesto
Leite Rolim Neto. "Impact of Sars-Cov-2 and its reverberation in global higher education and mental health." Psychiatry Research 288, p.112977, (2020).

3Wu, Peng, Xinxin Hao, Eric HY Lau, Jessica Y. Wong, Kathy SM Leung, Joseph T. Wu, Benjamin J. Cowling, and Gabriel M. Leung. "Real-time tentative assessment of the epidemiological characteristics of novel coronavirus infections in Wuhan, China, as at 22 January 2020." Eurosurveillance 25, no. 3, p. 2000044, (2020).

4Alamo, Teodoro, Daniel G. Reina, Martina Mammarella, and Alberto Abella. "Open data resources for fighting covid-19." arXiv preprint arXiv:2004.06111, (2020).

5Huang, R. H., D. J. Liu, A. Tlili, J. F. Yang, and H. H. Wang. "Handbook on facilitating flexible learning during educational disruption: The Chinese experience in maintaining undisrupted learning in COVID-19 Outbreak." Beijing: Smart Learning Institute of Beijing Normal University, (2020).

6World Health Organization. "World health statistics 2020: monitoring health for the SDGs, sustainable development goals.", (2020).

7Porcheddu, Rossella, Caterina Serra, David Kelvin, Nikki Kelvin, and Salvatore Rubino. "Similarity in case fatality rates (CFR) of COVID-19/SARS-COV-2 in Italy and China." The Journal of Infection in Developing Countries 14, no. 02, pp.125-128, (2020).

8Moriarty, Kate. "Achieving SDG4 through a human rights based approach to education.", (2017).

9Cantillo, Raffaella. "School v. Schools: Is Italy Shying Away From Italy? Understanding Government and Institutional Practices in Italy From Within an Educational Framework." Journal of Education and Development 3, no. 3, p. 63, (2019).

10 Nacoti, Mirco, Andrea Ciocca, Angelo Giupponi, Pietro Brambillasca, Federico Lussana, Michele Pisano, Giuseppe Goisis et al. "At the epicenter of the Covid-19 pandemic and humanitarian crises in Italy: changing perspectives on preparation and mitigation." NEJM Catalyst innovations in care delivery 1, no. 2, (2020).

11Naziev, Aslanbek. What is an education?. In Conference Proceedings. The Future of Education (p. 436). libreriauniversitaria. it Edizioni,(2017).

12Montjouridès, Patrick, and Ji Liu. Data and evidence on education in emergencies. No. ARTICLE, 2019.

13Ellis, B. Heidi, Jeffrey P. Winer, Kate Murray, and Colleen Barrett. "Understanding the mental health of refugees: Trauma, stress, and the cultural context." The 
Massachusetts General Hospital textbook on diversity and cultural sensitivity in mental health , pp. 253-273, (2019).

14Burde, Dana, Amy Kapit, Rachel L. Wahl, Ozen Guven, and Margot Igland Skarpeteig. "Education in emergencies: A review of theory and research." Review of Educational Research 87, no. 3, pp.619-658, (2017).

15Khan, Kamran, Jennifer Sears, Vivian Wei Hu, John S. Brownstein, Simon Hay, David Kossowsky, Rose Eckhardt et al. "Potential for the international spread of Middle East respiratory syndrome in association with mass gatherings in Saudi Arabia." PLoS currents 5, (2013).

16Loader, Rebecca, Joanne Hughes, Violeta PetroskaBeshka, and Ana Tomovska. "JOURNAL ON EDUCATION IN EMERGENCIES.", (2018).

17Sun, Kaiyuan, Jenny Chen, and Cécile Viboud. "Early epidemiological analysis of the coronavirus disease 2019 outbreak based on crowdsourced data: a population-level observational study." The Lancet Digital Health 2, no. 4, pp. e201-e208, (2020).

18Paules, Catharine I., Hilary D. Marston, and Anthony S. Fauci. "Coronavirus infections-more than just the common cold." Jama 323, no. 8, pp. 707-708, (2020).

19Setiawan, Adib Rifqi. "Scientific literacy worksheets for distance learning in the topic of Coronavirus 2019 (COVID-19)." EdArXiv. DOI: https://doi. org/10.35542/osf. io/swjmk, (2020).

20Kumari, Binita, B. S. Chandel, and Priyanka Lal. "Profit Efficiency among Dairy Farms in the Eastern Region of India." Indian Journal of Economics and Development 16, no.1, pp. 97-103, (2020).

21Parry, Nicola MA. "COVID-19 and pets: When pandemic meets panic." Forensic Science International: Reports 2, p.100090, (2020).

22Hui, David S., Esam I. Azhar, Tariq A. Madani, Francine Ntoumi, Richard Kock, Osman Dar, Giuseppe Ippolito et al. "The continuing 2019-nCoV epidemic threat of novel coronaviruses to global health-The latest 2019 novel coronavirus outbreak in Wuhan, China." International journal of infectious diseases 91, pp. 264266, (2020).

23Leonardi, Daniela, Annalisa Murgia, Marco Briziarelli, and Emiliana Armano. "The ambivalence of logistical connectivity: a co-research with Foodora Riders." Work Organisation, Labour \& Globalisation 13, no. 1, pp. 155171, (2019)
24Mazzucato, Mariana. "Mission-oriented research \& innovation in the European Union." European Commission, (2018).

25Burde, Dana, Amy Kapit, Rachel L. Wahl, Ozen Guven, and Margot Igland Skarpeteig. "Education in emergencies: A review of theory and research." Review of Educational Research 87, no. 3, pp. 619-658, (2017).

26Contini, Dalit, Federica Cugnata, and Andrea Scagni. "Social selection in higher education. Enrolment, dropout and timely degree attainment in Italy." Higher Education 75, no. 5, pp. 785-808, (2018).

27Comi, Simona Lorena, Gianluca Argentin, Marco Gui, Federica Origo, and Laura Pagani. "Is it the way they use it? Teachers, ICT and student achievement." Economics of Education Review 56, pp. 24-39, (2017).

28Türk, Umut. "Socio-economic determinants of student mobility and inequality of access to higher education in Italy." Networks and Spatial Economics 19, no. 1, pp. 125-148, (2019).

29Rogers Van Katwyk, Susan. "Policy and regulatory interventions to reduce antimicrobial resistance: evidence and analytic strategies." PhD diss., Université d'Ottawa/University of Ottawa, (2019).

30Macaro, Ernesto, Samantha Curle, Jack Pun, Jiangshan An, and Julie Dearden. "A systematic review of English medium instruction in higher education." Language Teaching 51, no. 1, pp. 36-76, (2018).

31Balzer, William K. Lean higher education: Increasing the value and performance of university processes. CRC Press, 2020.

32Ansah, Francis. "A strategic quality assurance framework in an African higher education context." Quality in Higher Education 21, no. 2, pp. 132-150, (2015)

33Mudavanhu, Young. "Quality of Literature Review and Discussion of Findings in Selected Papers on Integration of ICT in Teaching, Role of Mentors, and Teaching Science through Science, Technology, Engineering, and Mathematics (STEM)." Educational Research and Reviews 12, no. 4, pp. 189-201, (2017).

34 Teegavarapu, Sudhakar, Joshua D. Summers, and Gregory M. Mocko. "Case study method for design research: A justification." In International design engineering technical conferences and computers and information in engineering conference, vol. 43284, pp. 495-503, (2008).

35 White, Marilyn Domas, and Emily E. Marsh. "Content analysis: A flexible methodology." Library trends 55, no. 1, pp. 22-45, (2006). 
36 Gürel, Emet, and Merba Tat. "SWOT analysis: a theoretical review." Journal of International Social Research 10, no. 51, (2017).

37 Fernandes, Leão José, and F. Saldanha da Gama. "Contingency planning-a literature review." SCM Competitiveness. Macmillan, India, pp. 457-467, (2008). 


\section{Appendix A: A Case Study: University of Milan-Bicocca}

This paragraph is phrased as reported by a faculty member in an Italian University based on 100 documents of guidelines and instructions from his university administration. "Every university has its own procedures and techniques to manage the emergency. I would speak at least about my university (University of Milan-Bicocca). It is a new public university founded in 1998, with 35000 students. The university is equipped with modern teaching and research technologies; almost all teaching rooms are equipped with PODIO (i.e. smart computer for presentations, elaborations, smart board, video and audio recording). Therefore, from the first days of the emergency, the university was not in a big problem compared to other universities in Italy. The university is also equipped with a license for video recording from home called Kaltora capture. Some teachers use Microsoft Teams or WebEx and some go to the university to record their video classes with no students, and follow-up their classes from home at the same schedule of classes.

In general, universities depend so much on oral and written exams, so in this sense there was no problem to make oral exams online from home. The problem arises in the written exams, since it is difficult to make enough surveillance on students, but in the last days, the university has agreed to conduct written exams. They are based on closed questions, while open questions to be made in an oral way, and they approved to use e-proctoring for written exams. Anyway, the university has never closed its doors, and any professor could work at the university. There was another problem with graduate students. The university has approved WebEx for discussing master thesis with priority to finish all exams before they discuss their theses." 


\section{Appendix B: SOWT Analysis of the Italian Education System}

\section{SOWT Analysis of Education System}

\begin{tabular}{|l|c|}
\hline \multicolumn{4}{|c|}{ Strengths } \\
\hline - $\quad$ Italy has started to reform education
\end{tabular}
following other European countries since 2000/2001.

- Tuition fees are affordable; anyone can enroll in any university or institute.

- University commission conducts visits to schools to ensure the educational objectives are being met.

- A national assessment committee reviews the annual assessment of instructors and students.

- Teachers should attend a two-year course to qualify and obtain a tenured position.

- Focus on professional education and technology for better jobs opportunities.

- Professors develop research, integrate, and apply it into their teaching practices.

- Bologna declaration regarding reform and quality of education was announced in an Italian oldest university in the world.

- PHD candidate should pass a qualification exam and complete original research leading to dissertation.

- Approved e-proctoring for written exams, and online using WebEx for oral exams and Thesis defense at homes, with priority for graduate students.

- Families play a key role; they keep connected with schools to monitor the level of their kids.

- The educational policy pays attention to teachers' preparation and qualifications.

- In 2007, the Ministry of Education launched a National Plan for Digital Schools to employ ICT in classrooms.

\begin{tabular}{|c|}
\hline Opportunities \\
\hline
\end{tabular}

- Effective use of ICT in teaching and learning.

- Some universities offer a penalization or postgraduate degree courses to enhance students' professional skills.

- Universities produce fewer graduates than most of other western countries.

\section{Weaknesses}

- Only $44 \%$ of the population has basic digital skills compared with the EU average of $56 \%$.

- There was no emergency plan in Italy for education. It requested the EU for help.

- The official teaching language, except language sciences, is the Italian.

- In coronavirus crises, many students stop learning because the labs were closed.

- They emergency announcement was too late, hence many Covid-19 cases.

- ICT is not used thoroughly in education.

- Schools suffer from dropout (EC 2018).

\section{Threats}

- The private universities ask for high fees.

- Written and oral examinations cannot be replaced or ignored.

- Each university has its own procedures and techniques to manage the emergency. 


\begin{tabular}{|l|l|}
\hline $\begin{array}{l}\text { Students participate in International } \\
\text { Student Assessment programs like PISA. }\end{array}$ & $\begin{array}{l}\text { ICT infrastructure variance among } \\
\text { governmental and private/modern and old } \\
\text { HEIs or schools. }\end{array}$ \\
& $\begin{array}{l}\text { Wide gap between results of northern } \\
\text { schools, which are significantly better than } \\
\text { southern schools. } \\
\text { Teaching quality and student performance } \\
\text { of public schools are better than private } \\
\text { ones. }\end{array}$ \\
\hline
\end{tabular}




\section{Appendix C: The Proposed Contingency Plan}

\begin{tabular}{|c|c|c|c|c|c|}
\hline \multicolumn{6}{|c|}{ Appendix C: The Proposed Contingency Plan for E ducational Continuity in Italy } \\
\hline No. & Strategic Objective & Sub Objective & Programs-Activities & Took & Indicators \\
\hline \multirow{6}{*}{1} & \multirow{6}{*}{$\begin{array}{l}\text { Increasing Aw areness Level } \\
\text { for education stakeholders. }\end{array}$} & \multirow{3}{*}{$\begin{array}{l}\text { 1-1 Developing awareness } \\
\text { programs related to protection } \\
\text { and prevention against spread } \\
\text { of Covid-19. }\end{array}$} & $\begin{array}{l}\text { Awar eness about Coronavirus (Symptoms and ways of preventing and } \\
\text { controlling the disease). }\end{array}$ & $\begin{array}{l}\text { posters, workshop, school Morring } \\
\text { broadcast, school website, etc. }\end{array}$ & $\begin{array}{l}100 \% \text { of people are aware of the } \\
\text { coronatirus }\end{array}$ \\
\hline & & & $\begin{array}{l}\text { Providing gui delines for using hand sanitizers such as soap, alcohol, } \\
\text { and anti septic hygiene gel for the school students and stuff at } \\
\text { entrances, exits, and toilets. }\end{array}$ & TV, newspapers, social media & $\begin{array}{l}100 \% \text { of schools know about the } \\
\text { guidelines }\end{array}$ \\
\hline & & & Ensure safe school environment through deaning activities. & $\begin{array}{l}\text { Clean school walls, equipment, doors } \\
\text { and windows handles, and washing } \\
\text { hands with hot water. }\end{array}$ & All schools have safe environm ent \\
\hline & & \multirow{3}{*}{$\begin{array}{l}\text { 1.2 Developing awareness } \\
\text { programs regarding teaching } \\
\text { andlearring from home. }\end{array}$} & Guidelines for developing online material & $\begin{array}{l}\text { YouTube, Social media, Manuals and } \\
\text { guides }\end{array}$ & $\begin{array}{l}\text { All teachers are aware of online } \\
\text { material }\end{array}$ \\
\hline & & & Broadcasting TV programs about teaching from distance. & Interviews with key stakeholders & 30 interviews per month \\
\hline & & & Arnouncements and official letters from the MoE. & $\begin{array}{l}\text { e-Mails, News goups and Social } \\
\text { media }\end{array}$ & Reach $90 \%$ of beneficiaries \\
\hline \multirow{10}{*}{2} & \multirow{10}{*}{$\begin{array}{l}\text { Evaluation of current situation } \\
\text { and decision making } \\
\text { regarding the procedure for } \\
\text { education continuity during } \\
\text { the crisis. }\end{array}$} & \multirow{4}{*}{$\begin{array}{l}\text { 2-1 Periodical evaluation of } \\
\text { current situation }\end{array}$} & $\begin{array}{l}\text { Moritoring the spread of covid-19 in collaboration with the Ministry } \\
\text { of Health }\end{array}$ & $\begin{array}{l}\text { Local and International reports and } \\
\text { news. }\end{array}$ & Publish reports everyday \\
\hline & & & Consulting the ex perts regarding current situation & $\begin{array}{l}\text { Expectations and out ook, case } \\
\text { studies and research based on data } \\
\text { analysis }\end{array}$ & $\begin{array}{l}\text { Conduct meetings with experts as } \\
\text { necessary }\end{array}$ \\
\hline & & & $\begin{array}{l}\text { Study the altematives and the available options for continuing the } \\
\text { educational process through scientificresearch }\end{array}$ & Research papers, articles & $\begin{array}{l}10 \text { research papers or articles at } \\
\text { leastper week }\end{array}$ \\
\hline & & & $\begin{array}{l}\text { Evaluate the schools, teachers and sudents requirements, resources } \\
\text { and budget to implement consultation recommendations. }\end{array}$ & $\begin{array}{l}\text { Evaluation studies, databases, } \\
\text { exchange of expertise }\end{array}$ & Get reports from all schools \\
\hline & & \multirow{3}{*}{$\begin{array}{l}\text { 2-2 Decision making on } \\
\text { resources and tools of teaching } \\
\text { andlearning during } \\
\text { emergency. }\end{array}$} & Decide on the dosure or opening of Schools based on the evaluation. & Evaluation reports & Updates every 14 days \\
\hline & & & Decide on the procedure to be followed in either cases. & Evaluation reports & Updates every 14 days \\
\hline & & & $\begin{array}{l}\text { Decide on the necessary resources and tool sin order to continue the } \\
\text { educational process in collaboration with the stakehol ders. }\end{array}$ & Evaluation reports & Updates every 14 days \\
\hline & & \multirow{3}{*}{$\begin{array}{l}\text { 2.3 Providing requirements for } \\
\text { teaching andlearning } \\
\text { continuity. }\end{array}$} & $\begin{array}{l}\text { Provide the necessary resources, tool s and budget in or der to continue } \\
\text { the educational process. }\end{array}$ & $\begin{array}{l}\text { Expert teachers, schools and homes } \\
\text { ICT infrastructure, experience of } \\
\text { students }\end{array}$ & $\begin{array}{l}\text { Provide all requirem ents to } \\
\text { teachers and students }\end{array}$ \\
\hline & & & $\begin{array}{l}\text { Provide digital devices and Internet connection in collaboration with } \\
\text { ISPs, Ministry of Telecommurication (Responsible parties), local } \\
\text { community and private sector. }\end{array}$ & $\begin{array}{l}\text { Expert teachers, schools and homes } \\
\text { ICT infrastructure, experience of } \\
\text { students }\end{array}$ & $\begin{array}{l}\text { Provide all requirements to } \\
\text { teachers and students }\end{array}$ \\
\hline & & & $\begin{array}{l}\text { Manage the process and the strategy for education with the minimum } \\
\text { loss of resources and with the maximum possible quality. }\end{array}$ & $\begin{array}{l}\text { Teaching and leaming strategies, } \\
\text { Quality policies and standards }\end{array}$ & $\begin{array}{l}\text { Provide all suggested strategies, } \\
\text { policies and standards }\end{array}$ \\
\hline \multirow{3}{*}{3} & \multirow{3}{*}{$\begin{array}{l}\text { Developing training progams } \\
\text { related to emerging teaching } \\
\text { andlearring methods }\end{array}$} & $\begin{array}{l}\text { 3-1 Develop digital literacy } \\
\text { training programs }\end{array}$ & $\begin{array}{l}\text { Provide training programs for students, teachers and families on } \\
\text { general ICT and digtal technologies. }\end{array}$ & $\begin{array}{l}\text { Trainers, Online training platf orms, } \\
\text { Training material such as videos }\end{array}$ & $\begin{array}{l}\text { Provide sufficient training } \\
\text { programs on using ICT in } \\
\text { education }\end{array}$ \\
\hline & & \multirow{2}{*}{$\begin{array}{l}\text { 3.2 Develop training progr ams } \\
\text { on the educational tools and } \\
\text { methods of distance learming }\end{array}$} & $\begin{array}{l}\text { Provide training for administ ative and academic staff on the proposed } \\
\text { tools sincluding e-learning platforms and virtual classrooms. }\end{array}$ & $\begin{array}{l}\text { Trainers, Online training platforms, } \\
\text { Training material such as videos }\end{array}$ & $\begin{array}{l}\text { Provide sufficient training } \\
\text { programs on using ICT in } \\
\text { education }\end{array}$ \\
\hline & & & $\begin{array}{l}\text { Provide training for students and their parents to keep students } \\
\text { motivated and to encourage them to continue leaming from distance. }\end{array}$ & $\begin{array}{l}\text { Tr ainers, Online training platf orms, } \\
\text { Tr aining material such as videos }\end{array}$ & $\begin{array}{l}\text { Provide sufficient training } \\
\text { programs on using ICT in } \\
\text { education }\end{array}$ \\
\hline
\end{tabular}




\section{خطة طوارئ مقترحة لاستمرارية التعليم في ظل جائحة}

\section{كوفيد 19}

سميرة لطفي محمود عليان

كلية العلوم التربوية واعداد المعلمين جامعة النجاح الوطنية

$$
\text { كلية العلوم التربوية وطية محمد ترتير صفية النية المعلمين }
$$

$$
\begin{gathered}
\text { كلية العلوم التربوية أحمد فيصل صبّاح اعداد المعلمين } \\
\text { جامعة النجاح الوطنية }
\end{gathered}
$$

samira.mahmoud@stu.najah.edu safyyah.atyyah1983@gmail.com kifaya.sabbah@stu.najah.edu

$$
\text { قبول البحث: 25/7/2021 }
$$$$
\text { استلام البحث: 2021/6/6 }
$$

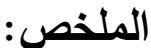

هدفت هذه الدراسة إلى وضع خطة طوارئ لاستمرار التعليم خلال جائحة كوفيد-19. قام الباحثون بدراسة الخطط الحالية لوضع خطة مناسبه لفلسطين، حيث تمت مراجعة الدراسات السابقة للاستفادة منها. وكانت النتيجة وضع خطة طوارئ مناسبة لازمة كوفيد-19. شملت الخطة الاستعداد، وتقديم الإسعافات الأولية، الاخذ برأي الثركاء، وتجهيز التعليمات قبل استقبال الردود قبل وصول الإسعافات الأولية. بتضمن الاستعداد خمس مهمات، الوقاية والحماية والتخفيف والاستجابة والتعافي. نم اعتماد التحليل البيئي لتبيان نقاط للقوة والضعف الفرص والتهديدات، والمقابلة الثخصية، من خلال دراسة حالة تشمل الخطة بجميع أبعادها نحو كيفية التصرف أثناء الجائحة. وضع الباحثن بعض التوصيات لكل من المعلمين والطلاب، من أبرز التوصيات، أنه يجب على المعلمين التدرب على كيفية استخدام تكنولوجيا المعلومات والاتصالات في التعليم، كما يجب على الطلاب إظهار سلوك إيجابي تجاه استخدام تكنولوجيا المعلومات والاتصالات في تعلمهم.

الكلمات المفتاحية: خطة طوارئ، جائحة كورونا كوفيد 19. 